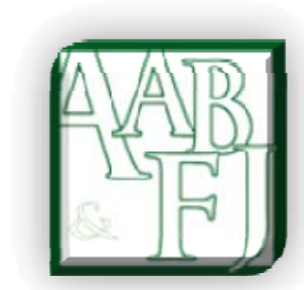

\title{
The Use of Fair Value and Historical Cost Accounting for Investment Properties in China
}

\author{
Ross Taplin, Wei Yuan and Alistair Brown ${ }^{1}$
}

\begin{abstract}
This paper examines the use of fair value accounting for investment properties by 96 randomly selected Chinese listed companies' year-ending 2008 annual reports. Half the sampled companies use fair value while half use historical cost, both methods being allowable under International Financial Reporting Standards (IFRS) and Chinese Accounting Standards (CAS). This represents the lowest possible level of comparability (or harmony) when there are only two choices of method. A combination of $\mathrm{T}$ indices to summarise the level of comparability and logistic regression reveals that companies with an international influence (listed on international stock exchanges and/or with international operations) are more likely to use fair value. Furthermore, there is evidence that companies with above average volatility in earnings are more likely to use fair value than historical cost. The consequences for domestic and international harmony for regulators and investors is discussed in the context of the opening of Chinese markets to international investment.
\end{abstract}

JEL Classification: M40

Keywords: fair value, investment properties, accounting policy choice, China

\footnotetext{
${ }^{1}$ Alistair.Brown@cbs.curtin.edu.au
} 


\section{Introduction}

Fair value accounting (FVA) has aroused much interest since FASB 157 Fair Value Measurements was first issued (Landsman 2006; Maines \& Wahlen 2006; Owusu-Ansah \& Yeoh 2006; Bahal et al. 2008; Christensen \& Nikolaev 2008; Muller et al. 2008; Peng 2008). FVA is defined as the price that would be received to sell an asset or paid to transfer a liability in an orderly transaction between market participants at the measurement date, and is deemed more relevant and reliable than historical cost (Bahal et al. 2008). Its implementation has proved problematic due to its complex and controversial nature however.

This paper extends the study of Muller et al. (2008) on the fair value of investment property of European companies to a Chinese setting. Using agency theory, the main purpose of this paper is to detect the extent and determinants of investment properties valuation basis of Chinese listed companies. Although this study relies on constructions mainly based on Western countries' ideas of a market-orientated study, we argue that China's particular circumstances warrant such an approach. China's property market has rapidly expanded in recent times (Ke \& White 2009) with a high percentage of Chinese foreign investment devoted to properties in Chinese cities ( $\mathrm{Li}$ et al. 1999). In addition, a huge pool of quality property investment is currently held by commercial banks, developers, and government (Wang et al. 2009). Quek and Ong (2008) also note the emergence of the rapid growth of the Chinese real estate market and real estate investment trusts (REITs). This is because the Chinese economy has outperformed most developed economies over the past decade, a fact that is commensurately reflected in the rapid growth of the Chinese real estate market (Quek and Ong 2008).

It is important to note, however, that there are important cultural and legal differences in the approaches to investment property taken by Chinese and Western firms. No one holds ownership of land in China as it is a state-owned asset. It may be the intangible value associated with the land that appreciates, rather than the building itself, which stands as a physical object that mostly depreciates when maturing. Further, Deloitte (2011) recognises that while market transparency of Chinese real estate investment contracts has improved in recent years, there are still some issues that impact on the timing of due-diligence periods and the costs of contractual transactions. These issues include the lack of accurate property sale and lease transaction data, the lack of statistics on demand and supply for property investment, and the lack of centralised data on property investment. This makes the empirical assessment of why Chinese companies apply either FVA and HC for investment properties all the more intriguing.

The research question is expressed as:

What are the characteristics of Chinese companies that use fair value accounting rather than historical cost accounting for investment properties?

The study uses harmony indices and binary logistic regression to consider what potential hypotheses might answer this question. The contribution of this study is two-fold. First of all, it answers the call made by Fieldset al. (2001) for more research regarding accounting policy choice. The economic implications of accounting choices continue to generate considerable interest among some researchers (Fields et al. 2001). There are economic-based motivations for managers to select accounting techniques that may result in more income-increasing or income-decreasing reported earnings (Watts \& Zimmerman 1986; Skinner 1993). The economic factors from a positive accounting theory perspective are used to explain the management's choice of accounting policies in this paper. 
This study then provides evidence regarding companies' reporting in China. As FVA is a major component of International Financial Reporting Standards (IFRS), the findings provide insights on global challenges to international accounting convergence. To promote convergence between national and international standards, CAS No3 Investment Real Estate (2006), which is a domestic standard on investment property, was issued to comply with IAS 40 Investment Property The results of this paper can reveal the information and insights into this convergence.

This paper is presented in five sections. Section 2 provides the literature review and hypothesis development. This is followed by Section 3 on the research methods. Section 4 provides the empirical results and Section 4 discusses the implications of the findings in relation to the theoretical framework.

\section{Literature Review and Hypothesis Development}

IAS 40 Investment Property defines investment property as property (land or a building - or part of a building - or both) held (by the owner or by the lessee under a finance lease) to earn rentals or for capital appreciation or both, rather than for: (a) use in the production or supply of goods or services or for administrative purposes; or (b) sale in the ordinary course of business (IAS 40.5).

Subsequent to initial recognition at cost, IAS 40 Investment Property requires firms to choose between the cost and fair value models and apply the chosen policy to all of their investment property. Under the cost model, firms apply the requirements of IAS 16 Property, Plant and Equipment (IAS 40.56) pertaining to this method, according to which investment property is carried at its cost less any accumulated depreciation and any accumulated impairment losses (IAS 16.30). Notably, however, fair value must be disclosed in the footnotes, except where, under exceptional circumstances, fair value cannot be determined reliably (IAS 40.79 (e)).

Under the fair value model, investment property is carried on the balance sheet at fair value (IAS 40.33), with all changes in fair value reported in the income statement (IAS 40.35). The fair value of investment property is the price at which the property could be exchanged between knowledgeable, willing parties in an arm's length transaction (IAS 40.5). It is determined under a fair value hierarchy described in IAS 40.45-47, where the best evidence of fair value is given by current prices in an active market for similar property in the same location and condition and subject to similar lease and other contracts. Firms are encouraged, but not required, to enlist independent valuers (for example, appraisers) with relevant qualification and experience when determining fair value (IAS 40.32).

IAS 40 is significant as it was the first time the International Accounting Standards Board (IASB) introduced a fair value accounting model for non-financial assets. Further, all firms must provide fair values for their real estate assets - either directly on the balance sheet under the fair value model choice, or within the footnotes under the cost model choice. However, since only the fair value model results in unrealised fair value gains or losses flowing through income, the choice between the two models affects reported income and net asset value volatility. Interestingly, the standard further states that firms have the option of switching from the cost model to the fair value model. In contrast, the standard explicitly states it is highly unlikely that fairer presentation will be achieved by a switch from the fair value to the cost model, which is therefore prohibited (IAS 40.30).

Effective from January 1, 2007, Chinese Accounting Standards (CAS) converged with International Financial Reporting Standards. Similar to IFRS, a separate chapter, CAS NO.3 Investment Real Estate, is devoted to accounting of investment property. In this regulation, investment property is called investment real estate, and is defined as 'the real estate held for 
generating rent and/or capital appreciation' (CAS 3.2). Recognition criteria is couched in the following terms:

No investment real estate shall be recognized unless it meets the following requirements simultaneously:

(1) The economic benefits pertinent to this investment real estate are likely to flow into the enterprise; and

(2) The cost of the investment real estate can be reliably measured (CAS 3.6).

Further, Article 7 states that the initial measurement of the investment real estate should be made at its cost. Similar to IAS 40, subsequent to initial recognition at cost, CAS No. 3 also requires firms to choose between the cost and fair value models and apply the chosen policy to all of their investment property. Under the cost model, firms apply the requirements of CAS No.4 - Fixed Assets to the follow-up measurement of a building measured through the cost pattern. Intangible assets apply to the follow-up measurement of the right to the use of the land measured through the cost pattern (CAS 4.9). However, in contrast to CAS No.4 Fixed Assets, IAS 16 Property, Plant and Equipment does not require the disclosure of fair value in the footnotes (IAS 40.79 (e)).

Under the fair value model, investment property is carried on the balance sheet at fair value when there is an active trading market of real estate in the location of the investment real estate (CAS 4.10(1)), and the enterprise is able to obtain the market prices of identical or similar real estates and other relevant information from the trading market of real estate, so as to be able to estimate the fair value of the investment real estate (CAS 4.10(2)). Particularly, the book value of fair value is adjusted on the basis of its fair value on the date of the balance sheet, and the difference between the fair value and its original book value is included in the current profits and losses (CAS 4.11).

Quite similar to IAS, CAS requires that once an enterprise's pattern for the measurement of the investment real estate is decided, it cannot be changed randomly. If the enterprise replaces the cost pattern by the fair value pattern, it will be deemed that it has changed its accounting policy, which is in accordance with the CAS 28 Changes in Accounting Policies and Estimates and Correction of Errors. However, for an investment real estate that has been measured through the fair value pattern, the pattern of its measurement will not be changed from the fair value pattern to the cost method (CAS 4.12).

Notably, compared with IAS, which states that firms are encouraged, but not required, to enlist independent valuers (appraisers) with relevant qualifications and experience when determining fair value (IAS 40.32), CAS does not mention anything about the reliable values.

As outlined earlier, fair value accounting is defined in FASB 157 Fair Value Measurement as the price that would be received to sell an asset or paid to transfer a liability in an orderly transaction between market participants at the measurement date. It requires certain methods to be used to measure fair value: measured as a market-based measurement, not an entity-specific measurement, and based on assumptions market participants would make in pricing the asset or liability. ${ }^{2}$

Positive accounting theory has made a significant contribution to our understanding of corporate reporting practices (Williams 2003; Watts \& Zimmerman 1986). In particular, it

\footnotetext{
${ }^{2}$ To measure fair value accurately, a three level hierarchy is given as follows: Level 1 inputs are quoted prices (unadjusted) in active markets for identical assets or liabilities that the reporting entity has the ability to access at the measurement date; Level 2 inputs are inputs other than quoted prices included within Level 1 that are observable for the asset or liability, either directly or indirectly; and Level 3 inputs are unobservable inputs for the asset or liability. FASB 157 emphasises that fair value is market based rather than company specific. FASB 157 assumes that market participants will use fair value in pricing the asset.
} 
has provided an explanation of managers' choices among accounting methods in terms of the underlying trade-off between these various incentives (Beattie et al. 1994). Agency theory is an important construct of positive accounting theory: it has been a popular conceptual framework for researchers interested in subjects such as conflicts of interest, matters of accounting choice, incentive problems and mechanisms for managing incentive problems (Guilding et al. 2005).

The accounting literature reports a correlation between firms' accounting choice and other variables, such as leverage and size, and signs of these correlations are mostly consistent throughout the research (Christensen \& Nikolaev 2008). Gopalakrishnan (1994) predicts that the higher the firm's leverage, the more likely managers use accounting methods that increase equity. This arises as the higher the leverage, the closer the firm is to the constraints in the debt covenants (Kalay 1982). Debt covenants are agreed as a condition of borrowing. In addition to the agency conflict between stockholders and managers, there is a second class of agency conflicts: those between creditors and stockholders. Creditors have the primary claim on part of the firm's revenue in the event of bankruptcy. The stockholders, however, maintain control of the operating decisions (through the firm's managers) that affect the firm's cash flows and their corresponding risks (Watts \& Zimmerman 1986). To avoid the closeness to the covenant constraints, managers of firms are willing to use accounting techniques to reduce financial leverage (Fields et al. 2001). Watts and Zimmerman (1986) suggest that the ex-post managerial discretions can be made to increase compensation or to avoid debt covenant violations. Thus, the investment property can be revalued each year by adopting fair value basis, which provides the possibility of increasing the book value of total assets. This can reduce the firm's debt/asset leverage ratio. This is also supported by Christensen and Nikolaev (2008) in an IFRS adopter's sample. ${ }^{3}$ Thus, it is hypothesised:

\section{H1: Companies with higher leverage are more likely to use the fair value model.}

A proxy of earnings smoothing practices could also be a proxy of a manager's goal to reduce political costs, enhanced instead by variable reported profit (Watts \& Zimmerman 1978; Hagerman \& Zmijewski 1979). In other words, managers could manage accrual accounting to smooth current earnings in order to reduce political costs.

Another link between earnings smoothing behaviour and preference of cost model is represented by the cost of capital, another source of efficiency. Ball (2006) and Jermakowicz \& Gornik-Tomaszewski (2006) show that volatile earnings are a consequence of fair value adoption, especially induced by economic factors outside companies' control, such as a change in asset market prices (Ronen 2008; Whittington 2008). This volatility is one of the main arguments against the fair value method (Enria, et al.2004), as volatility is a strong capital cost driver (Fama 1977). Agency theory emphasises that managers have an incentive to present future debt holders with low volatility in earnings, thus lowering the required return of the debt holders and thereby reducing the firm's long-term cost of capital (Watts \& Zimmerman 1990).

The relationship between cost of capital and the adoption of fair value is investigated by Muller et al. (2008) as well: they find a negative correlation between fair value adoption and cost of capital, while no significant results are found after that period. Hence, it is hypothesised:

H2: Companies with higher variability of reported earnings are more likely to use the fair value model.

\footnotetext{
${ }^{3}$ Christensen and Nikolaev predicted a positive correlation between leverage and the fair value method in their European companies' sample.
} 
The value relevance of investment property fair values is acknowledged by many countries outside China (Lourenço \& Curto 2008). There is considerable demand for fair value particularly by foreign investors attempting to evaluate the investment quality and financial strength of these companies (Alfred 2005).

Chinese companies have options to list domestically or overseas. Overseas listing may spur additional investment in the Chinese market, and help entities play an increasingly global role through improved international comparative reporting (McCollum 2006). By listing overseas, the take-up of fair value accounting may improve. Thus, it is hypothesised:

H3: Chinese companies listed overseas are more likely to use the fair value model.

Agency theory assumes the presence of information asymmetry as one of the key factors that allows management, if it is so inclined, to pursue goals that are divergent from shareholders' interests (Watts \& Zimmerman 1990). It follows, therefore, that to be effective in protecting the company's shareholders, directors need to overcome this information asymmetry so that they will have a firm grasp of the business and the risks it faces (Plantin et al. 2008).

A firm's choice between the cost and fair value models may reflect the perceived demand for fair value information in the financial statements. A firm's financing and governance model is commonly viewed to be influential in this regard. Firms that are primarily insider-financed are more likely to cater to the payout preferences of their executive directors and CEOs, who may prefer low income volatility over transparent and timely information, as information asymmetry can be resolved via other communication channels (Muller et al. 2008). In contrast, where outsiders provide the majority of financing, there is likely to be stronger demand for transparent reporting and public disclosure to solve the information asymmetry problem. Hence it is hypothesised:

H4: Companies with its shares held by insiders are more likely to use the fair value model.

Similarly, firms competing in international real estate and capital markets are more likely to face a demand for transparent reporting, as managers may pursue goals that are divergent from shareholders' interests through information asymmetry (Watts \& Zimmerman 1986). That is, as the firm's investments become more dispersed, it is more difficult for owners to assess the performance and value of the properties, consistent with owners having both greater and lower-cost information about local property markets relative to non-local markets (Muller et al. 2008).

Some Chinese companies may have international operations and confront the issue of information asymmetry (Muller et al. 2010). To overcome information asymmetry and protect shareholders' interests, companies with international revenues are hypothesised as being more likely to use fair value for their investment properties:

H5: Companies with operations internationally are more likely to use the fair value model.

The conceptual schema underlying the testable hypothesis is provided below in Figure 1 . Note that apart from the five independent variables raised in the hypotheses' development, company size and industry type are included as two control variables. 
Figure 1. Conceptual schema

\begin{tabular}{|c|c|c|}
\hline Independent Variables & Control Variables & Dependent Variable \\
\hline $\begin{array}{l}\text { Efficiency: } \\
\text { 1. Leverage } \\
\text { 2. Earnings management } \\
\text { 3. Listing status } \\
\text { Information asymmetry: } \\
\text { 4. Internal executive directors } \\
\text { and CEOs } \\
\text { 5. International operations. }\end{array}$ & $\begin{array}{ll}\text { 1. } & \text { Size } \\
\text { 2. } & \text { Industry }\end{array}$ & $\begin{array}{c}\text { Investment Property } \\
\text { Valuation Base }\end{array}$ \\
\hline
\end{tabular}

\section{Research Approach}

A random sample of 96 Chinese companies with investment property valuations in their 2008 financial statements was utilised in this study. Since the presence of investment properties in the financial statement of companies is not known without examining the financial statements of all the listed companies, this was achieved in a two step process. Firstly, an initial random sample of companies listed on the two Chinese domestic stock exchanges, the Shanghai Stock Exchange and Shenzhen Stock Exchange, was obtained. Secondly, companies from this initial sample whose 2008 financial statements reported valuations of investment properties were retained for further analysis while the companies without investment properties were discarded. This sampling regime is equivalent to selecting a random sample of companies with investment property valuations in 2008 but without the need to identify which companies have investment properties prior to sampling. Under both CAS and IFRS there are only two valuation methods: historical cost accounting and fair value accounting. As in Muller et al. (2008) the dependent variable (valuation basis for investment property) was recorded as 1 (fair value) or 0 (historical cost) for each of these companies.

The independent variables were measured as follows. Leverage equals book value of total liabilities divided by book value of total assets (Christensen \& Nikolaev 2008). Following Leuz et al. (2003) and Burgstahler et al. (2006), the proxy to capture earnings smoothing activities is computed as the ratio of the standard deviation of operating income divided by the standard deviation of cash flow from the operation, both measures being computed over two years (2008 and 2007). Due to the large number of outliers in the distribution of this proxy, a dummy variable was utilised summarising whether this proxy was above or below the median. The independent variable earnings management was measured as one if this ratio was above the mean and zero if below the mean. Listing status was defined as 1 if the company was listed on an international stock exchange in addition to a domestic Chinese stock exchange. Following Muller et al. (2008), the percentage of shares 
outstanding that are held by executive directors and CEOs at the end of the fiscal year was attained. Under IFRS and CAS, the listed companies are required to report this information in the Report of Directors. Since $56 \%$ of the companies reported a percentage of zero the executive directors and CEOs variable was measured as 1 when directors and chief executives owned shares and 0 otherwise. ${ }^{4}$ International revenue was measured with a dummy variable equal to 1 when the company reported revenue from international (nonChinese) sources (0 otherwise) and listing status equal to 1 when the company was listed on an international (non-Chinese) stock exchange (0 otherwise). Companies listed internationally are either from the Hong Kong Stock Exchange or Singapore Stock Exchange.

The control variables were measured as follows. Industry equals 1 when the company is a real estate company (0 otherwise) and size equals the logarithm (base 10) of total assets. Total assets were recorded in Chinese Yuan.

Statistical analysis proceeded in two parts. First, harmony (or comparability) indices are used to summarise the extent to which companies use the same valuation method (fair value or historical cost). Herfindahl $\mathrm{H}$ indices (van der Tas 1988) are used for the total sample and separately for the companies listed domestically The between country C index (Archer et al. 1995) is used to summarise the comparability between domestic and international companies. This is a novel use of the between country $C$ index since in this paper it compares companies that are all Chinese but compares those listed domestically only with those listed domestically and internationally. These indices are both special cases of the $T$ index (Taplin. 2004) using options 1a2a3a4a to obtain the $\mathrm{H}$ index and options 1a2c3a4a to obtain the between country $\mathrm{C}$ index. These index values equal the probability that two randomly selected companies (from different countries in the case of the between country index) have comparable accounts in the sense that they use the same valuation of their investment property.

Second, binary logistic regression is used to test for relationships between the choice of valuation and the independent and control variables simultaneously. Logistic regression takes the form of a traditional multiple regression, however the expected value of a continuous dependent variable in the regression equation is replaced with the logodds the natural logarithm of the probability of using fair value divided by the probability of using historical cost). Thus positive coefficients for an independent variable indicate that the use of fair value is more prevalent when the independent variable is higher. Logistic regression coefficients are estimated using maximum likelihood and tested using Wald tests to obtain P-values.

\section{Results}

Half (48/96) of the randomly sampled companies used fair value accounting to value their investment properties with the other half using historical cost. This represents a low level of comparability (Herfindahl $\mathrm{H}$ index, or T index with options 1a2a3a4a, equal to 0.5). This is the lowest possible level of comparability when there are only two available options (in this case fair value and historical cost). The comparability is higher for companies listed domestically $(\mathrm{H}=0.69)$ or internationally $(\mathrm{H}=0.90)$ but comparability between domestic and internationally listed companies is very low $(\mathrm{T}=0.22$, options $1 \mathrm{a} 2 \mathrm{c} 3 \mathrm{a} 4 \mathrm{a})$. This is because companies listed domestically continue to use historical cost $(46 / 57=81 \%)$ while companies listed internationally are more likely to use fair value $(37 / 39=95 \%)$. Thus, even though all sampled companies are listed on a Chinese stock exchange, being listed on an international

\footnotetext{
${ }^{4}$ Results (not shown) are similar if the actual percentages are used. More importantly, it is possible some companies do not report this information, possibly because the shareholdings are not material.
} 
stock exchange as well is strongly related to the use of fair value and this reduces the level of comparability between Chinese listed companies. Logistic regressions presented below confirm listing status as the most statistically significant determinant of valuation choice.

Table 1 contains descriptive statistics for the two continuous variables: company size and leverage. After logarithmic transformation of total assets to derive size, both these variables are approximately normally distributed. Total assets vary from approximately 100 million to 100 billion Chinese Yuan while leverage is highly variable with a mean $=54 \%$.

Table 1. Descriptive statistics: company size and financial leverage

\begin{tabular}{|r|c|c|c|c|c|c|}
\hline & $\mathbf{N}$ & Min & Max & Mean & SD & Skewness \\
\hline Size & 96 & 8.1328 & 11.3011 & 9.7768 & 0.6337 & 0.158 \\
\hline Leverage & 96 & 9.99 & 95.12 & 53.81 & 18.59 & 0.033 \\
\hline
\end{tabular}

Nine companies had international revenue, 50 were in the real estate industry, 39 were listed on international stock exchanges and 54 of the 96 companies had internal executive directors and CEOs. ${ }^{5}$ Correlations between independent variables were all low except for a tendency for real estate companies to be less likely to have internal executive directors and CEOs ( $\mathrm{r}=-0.594)$, more likely to be listed internationally ( $\mathrm{r}=0.581)$ and be larger $(\mathrm{r}=0.416)$.

Table 2 summarises the results of three logistic regressions for the valuation choice of investment properties: with all independent and control variables included; with the insignificant independent variables excluded but control variables included; and with insignificant independent and control variables excluded. Results are similar due to the absence of multicollinearity and suggest listing status $(\mathrm{P}<.001)$ is highly significant, earnings management $(\mathrm{P}=.026)$ and international revenue $(\mathrm{P}=.031)$ are significant and size $(\mathrm{P}=.064)$ is a marginally significant predictor of valuation choice. Companies are more likely to use fair value for investment properties if they are listed on an international stock exchange, have international revenue, have higher volatility of reported earnings using accruals, and are smaller in size. Hence hypotheses H2, H3 and H5 are supported. Insignificant evidence is found in support of hypotheses $\mathrm{H} 1$ and $\mathrm{H} 4$ suggesting levels of debt and internal executive directors and CEOs do not influence the choice to value investment properties with fair value rather than historical cost. Most of the variation in the valuation of investment properties is explained by the independent variables, with Nagelkerke R Square exceeding 0.7 .

\footnotetext{
${ }^{5}$ By definition earnings management is above the median for half the companies.
} 
Table 2. Binary Logistic Regression results for choice of Fair Value Accounting

\begin{tabular}{|c|c|c|c|c|c|c|}
\hline & \multicolumn{2}{|c|}{ Regression 1} & \multicolumn{2}{|c|}{ Regression 2} & \multicolumn{2}{|c|}{ Regression 3} \\
\hline Variable & B & $P$ & B & $P$ & B & $P$ \\
\hline Leverage & -.159 & .934 & & & - & - \\
\hline $\begin{array}{c}\text { Earnings } \\
\text { Management }\end{array}$ & 1.830 & $.027 *$ & 1.798 & $.022^{*}$ & 1.678 & $.026^{*}$ \\
\hline $\begin{array}{c}\text { Internal } \\
\text { executive } \\
\text { directors and } \\
\text { CEOs }\end{array}$ & -1.309 & .316 & & & - & - \\
\hline $\begin{array}{c}\text { International } \\
\text { Revenue } \\
\end{array}$ & 1.899 & $.043^{*}$ & 1.951 & $.036^{*}$ & 1.982 & $.031^{*}$ \\
\hline Listing State & 6.247 & $000^{* * * *}$ & 6.172 & $.000 * * *$ & 5.830 & $.000 * * *$ \\
\hline Industry & -.693 & .483 & -.608 & .531 & - & - \\
\hline Size & -1.280 & .131 & -1.262 & .108 & -1.401 & .064 \\
\hline $\begin{array}{c}\text { CoxandSnell R } \\
\text { Square }\end{array}$ & \multicolumn{2}{|c|}{.532} & \multicolumn{2}{|c|}{.532} & \multicolumn{2}{|c|}{.527} \\
\hline $\begin{array}{l}\text { Nagelkerke R } \\
\text { Square }\end{array}$ & \multicolumn{2}{|c|}{.709} & \multicolumn{2}{|c|}{.709} & \multicolumn{2}{|c|}{.703} \\
\hline
\end{tabular}

$*$, **, *** indicate $\mathrm{P}<.05, \mathrm{P}<.01, \mathrm{P}<.001$ respectively

\section{Discussion}

Chinese companies are more likely to use fair value for investment properties if they are listed on an international stock exchange, have international revenue, have higher volatility of reported earnings and are smaller in size. Hypotheses H2 (earnings management), H3 (listing state) and H5 (international operations) are supported. Insignificant evidence is found in support of hypotheses H1 (leverage) and H4 (executive directors and CEOs). While companies only listed within China tend to use historical cost, companies listed on international stock exchanges tend to use fair value. Furthermore, even taking into account listing status there is further evidence that companies deriving part of their revenue from international (non-Chinese) sources are more likely to use fair value. Thus for Chinese companies the presence of an international influence correlates very strongly with the choice to use fair value to value investment properties.

The results of the study have implications for Chinese regulators. At present the situation in China provides the minimal level of comparability possible with half the companies using fair value and half using historical cost to value investment property. This produces sub-optimal information for investors since it makes the comparison of accounts of different companies more difficult. Consistent with the Lourenço \& Curto (2008) findings of the value relevance of investment property fair values outside China, Chinese companies listed on international stock exchanges appear to use the fair value method on international stock exchanges. For consistency between domestic and overseas markets there appears to be scope for Chinese accounting regulators to consider more rigorously the argument of fair value adoption. Consistent with Alfred (2005) there appears a considerable demand for fair value particularly by foreign investors attempting to evaluate the investment quality and financial strength of these companies. Chinese companies have options to list domestically or overseas, however if domestic companies are to attract foreign investment they too may benefit from the use of fair value for investment property. Overseas listing may spur 
additional investment in the Chinese market, and help entities play an increasingly global role through improved international comparative reporting (McCollum 2006). If Chinese regulators do not act to improve the comparability of company accounts, as is occurring throughout the world with the adoption of international conventions such as IFRS, then investment in Chinese companies may falter as investors turn to other markets where comparable information across companies is more readily assessable.

This study finds evidence that fair value accounting is significantly related to earnings management activities. This result may be due to the shortage of high-quality auditors and accountants. The CAS fair value requirements have created a surge in accounting work for the reliable assessment of fair value. However, China currently "has a shortfall of 300,000 qualified accountants and is likely to require a further three million over the coming years if it is to keep pace with its current rate of economic growth" (D’Souza 2007, pp. 1693-1694). Another possible explanation is that although the rules of CAS are relatively more mature than previous standards, earnings management may still exist in China. Hence, an improved market environment is still needed in China.

The international revenue hypothesis is marginally accepted. This is consistent with the result of Muller et al (2008). Chinese firms choosing the fair value model are more likely to have dispersed ownership, consistent with firms having concentrated ownership relying less on the reporting of fair values through the financial statements to mitigate information asymmetry.

In summary, listing status of a company can significantly affect the company's investment property valuation basis choice. When a company lists overseas, it is more likely to choose fair value accounting as their investment property valuation basis. This translates a lack of consistency between Chinese and international regulations into a low level of comparability between Chinese companies. Furthermore, the earnings smoothing activities, international revenue and company size appears to have some impact on the fair value choice for investment properties.

\section{References}

Alfred, J 2005, 'The Demand for Fair Value’, ACCA, Viewed 20 Feb 2013. http://www.accaglobal.com/members/publications/accounting_business/archive_by_topi c/countries/2005/2400987

Archer, S, Delvaille, P \& McLeay, S 1995, 'The Measurement of Harmonization and the Comparability of Financial Statement Items: Within-country and Between-Country Effects', Accounting and Business Research, Spring, vol. 25, no.98, pp. 67-80.

Bahal, A, Larson, E, Cristiano, J \& Sen, V 2008, 'Transactions Advisor Services: Dealing with Fair Value - Volatility in the Near Term', Viewed 20 Feb 2013, http://ftimedia.fticonsulting.com/resources/documents/trendwatch-june08.pdf

Ball, R 2006, 'International Financial Reporting Standards (IFRS): Pros and cons for Investors', Accounting and Business Research, International Accounting Policy Forum, pp. 5-27.

Beattie, V, Brown, S, Ewers, D, John, B, Manson, S, Thomas, D \& Turner, M 1994, 'Extraordinary items and Income Smoothin: A Positive Accounting Approach', Journal of Business Finance and Accounting, Demesetz, vol. 21, no. 6, pp. 791-811.

Burgstahler, DC, Hail, L \& Leuz, C 2006, 'The Importance of Reporting Incentives: Earnings Management in European Private and Public Firms', The Accounting Review, vol. 81, no. 5, pp. 983-1016

CAS No3 Investment Real Estate (2006) China Accounting Standards issued by the Ministry of Finance on 15 February 2006. Beijing. 
Christensen, HB \& Nikolaev, V 2008 'Who Uses Fair-Value Accounting for Non-Financial Assets Following IFRS Adoption', Viewed 6 March $2014 \quad \mathrm{~h}$ ttp://faculty.chicagobooth.edu/valeri.nikolaev/PDF/Christensen\%20and\%20Nikolaev\%2 02011\%20Does\%20fair\%20value\%20accounting\%20for\%20nonfinancial\%20assets\%20pass\%20the\%20market\%20test.pdfDeloitte 2011, China real estate investment handbook, Deloitte Touche Tohmatsu, Beijing.

D'Souza, D 2007, The way forward, IFRS, the Chartered Accountant (India), May,vol. 55, pp. 1692-1695. http://dx.doi.org/10.1016/S0165-4101(96)00438-7

Enria, A., Cappiello, L., Dierick, F., Grittini, S., Haralambous, A., Maddaloni, A. Molitor, P. A.M., Pires, F. and Poloni, P. (2004), Fair Value Accounting and Financial Stability (April). ECB Occasional Paper no. 13 . :Viewed 20 Feb 2013 http://ssrn.com/abstract=749044

Fama, E. F. 1977,,' Risk-Adjusted Discount Rates and Capital Budgeting under Uncertainty', Journal of Financial Economics, vol. 5, no. 1, pp. 3-24.

Fields, TD Lys, TZ \& Vincent, L 2001, 'Empirical Research on Accounting Choice’, Journal of Accounting and Economics, vol. 31, no. 1-3, pp. 255-307. http://dx.doi.org/10.1016/S0165-4101(01)00028-3

Gopalakrishnan, V 1994, 'Accounting Choice Decisions and Unlevered Firms: Further Evidence on Debt/Equity Hypothesis', Journal of Financial and Strategic Decisions, vol. 7, no. 3, pp. 33-47.

Guilding, C, Warnken, J, Ardill, A, and Fredline, L. 2005, 'An Agency Theory Perspective on the Owner/Manager Relationship in Tourism-Based Condominiums, Tourism Management, vol. 26, no. 3, pp. 409-420.

http://dx.doi.org/10.1016/j.tourman.2003.11.021

Hagerman, R \& Zmijewski, M 1979, 'Some economic determinants of accounting policy choice', Journal of Accounting and Economics, vol. 1, no. 2, pp. 141-61. http://dx.doi.org/10.1016/0165-4101(79)90004-1

IAS 40 Investment Property (2003) International Accounting Standards, International Accounting Standards Board, London.

Jermakowicz, EK \& Gornik-Tomaszewski, S 2006, 'Implementing IFRS from the perspective of EU publicly traded companies', Journal of International Accounting, Auditing and Taxation, vol. 15, no. 2, pp. 170-196. http://dx.doi.org/10.1016/j.intaccaudtax.2006.08.003

Kalay, A 1982, 'Stockholder-bondholder conflict and dividend constraints', Journal of Financial Economics, vol. 10, no. 2, pp. 211-233. http://dx.doi.org/10.1016/0304405X(82)90014-9

Ke, Q \& White, M 2009, 'An econometric analysis of Shanghai office rents', Journal of Property Investment \& Finance, vol. 27 no. 2, pp. 120-139. http://dx.doi.org/10.1108/14635780910937836

Landsman, WR 2006, 'Fair Value Accounting for Financial Instruments: Some Implications for Bank Regulation', Bank for International Settlements Paper.No. 209, Viewed at 6 March 2014, http://www.bis.org/publ/work209.pdf

Leuz, C, Nanda, D \& Wysocki, PD 2003, 'Earnings Management and Investor Protection: An International Comparison’, Journal of Financial Economics vol. 69, no. 3, pp. 505-527. http://dx.doi.org/10.1016/S0304-405X(03)00121-1

Li, L, Tse, R \& Ganesan, S 1999, 'Shanghai', in J Berry \& S McGreal (eds), Cities in the Pacific Rim: Planning Systems and Property Markets, E \& FN Spon, London, pp.45-66. 
Lourenço, IC \& Curto, JD 2008, 'The Value Relevance of Investment Property Fair Values (November, 14)’Viewed at 6 March 2014, http://ssrn.com/abstract=1301683 or http://dx.doi.org/10.2139/ssrn.1301683

Maines, LA \& Wahlen, JM 2006, 'The nature of accounting information reliability: inferences from archival and experimental research', Accounting Horizons, vol. 20, no. 4, pp. 399-425. http://dx.doi.org/10.2308/acch.2006.20.4.399

McCollum, T 2006, 'China adopts international standards', Internal Auditor, .

Vol.63(2), p.21 Muller, K, Riedl, E \& Sellhorn, T 2008, Consequences of Voluntary and Mandatory Fair Value Accounting: Evidence Surrounding IFRS Adoption in the EU Real Estate Industry: Working Paper 09-033, Harvard Business School, Boston.

Muller, K, Riedl, E \& Sellhorn, T 2010, Mandatory Fair Value Accounting and Information Asymmetry: Evidence from the European Real Estate Industry: Management Science,57, 1138-1153.

Owusu-Ansah, S \& Yeoh, J 2006, 'Relative value relevance of alternative accounting treatments of unrealized gains: implications for the IASB', Journal of International Financial Management and Accounting, vol. 17, no. 3, pp. 228-255. http://dx.doi.org/10.1111/j.1467-646X.2006.00128.x

Peng, SL \& Bewley, K 2008, Adaptability of Fair Value Accounting in China: Assessment of an Emerging Economy Converging with IFRS, Accounting, Auditing \& Accountability Journal, Vol. 23 Iss: 8, pp.982 - 1011 htt

Plantin, G., H. Sapra, and H. Shin. 2008. Marking-to-market: Panacea or Pandora's box? Journal of Accounting Research vol. 46, pp. 435-460.

Quek, CH \& Ong, SE 2008, Special Considerations for Designing Pilot REITs in China, Journal of Property Investment \& Finance, vol. 26 no. 3, pp. 247-274. http://dx.doi.org/10.1108/14635780810871623

Ronen, J 2008, ‘To Fair Value or Not to Fair Value: A Broader Perspective', Abacus, vol. 44, no. 2, pp. 181-208. http://dx.doi.org/10.1111/j.1467-6281.2008.00257.x

Skinner, DJ 1993, 'The Investment Opportunity Set and Accounting Procedure Choice: Preliminary Evidence', Journal of Accounting \& Economics, vol. 16, pp. 407-445. http://dx.doi.org/10.1016/0165-4101(93)90034-D

Taplin, RH 2004, 'A unified approach to the measurement of international accounting harmony’, Accounting and Business Research, vol. 34, no. 1, pp. 57-73.

van der Tas, LG 1988, 'Measuring Harmonization of Financial Reporting Practice', Accounting and Business Research, Spring, vol. 18, no. 70, pp. 157-69.

Wang, H, Sun, Y \& Chen, Y 2009, 'Special considerations for designing pilot REITs in China’, Journal of Property Investment \& Finance, vol. 27 no. 2, pp. 140-161. http://dx.doi.org/10.1108/14635780910937845

Watts, R \& Zimmerman, JL 1978, 'Towards a Positive Theory of the Determination of Accounting Standards', Accounting Review, vol. 51, no. 1, pp. 112-134.

Watts, R \& Zimmerman, JL 1986, Positive Accounting Theory, Prentice-Hall, Inc. Englewood Cliffs, New Jersey.

Watts, R \& Zimmerman, JL 1990, 'Positive Accounting Theory: A Ten Year Perspective', The Accounting Review, vol. 65, no. 1, pp. 131-156.

Whittington, G 2008, 'Fair Value and the IASB/FASB Conceptual Framework Project: An Alternative View', Abacus, vol. 44, no. 2, pp.139-178. http://dx.doi.org/10.1111/j.14676281.2008.00255.X

Williams, PF 2003, 'Modern Accounting Scholarship: The Imperatives of Positive Economic Science’, Accounting Forum, vol. 27, pp. 251-269. http://dx.doi.org/10.1111/1467$\underline{6303.00105}$ 